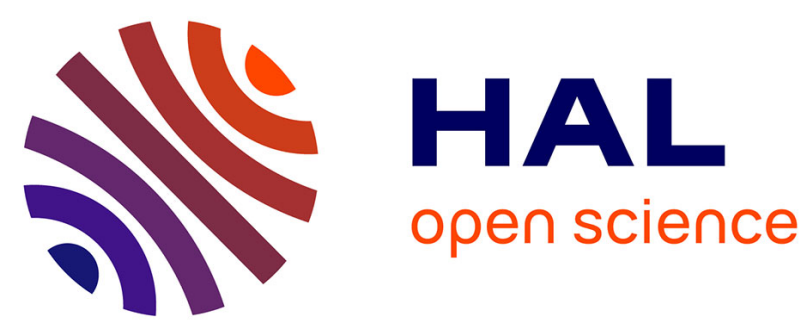

\title{
Perspectives from the French workshop on the development and validation of biomarkers and bioassays for the monitoring of aquatic environments
}

Wilfried Sanchez, T. Burgeot, O. Perceval

\section{- To cite this version:}

Wilfried Sanchez, T. Burgeot, O. Perceval. Perspectives from the French workshop on the development and validation of biomarkers and bioassays for the monitoring of aquatic environments. Environmental Science and Pollution Research, 2012, 19 (4), pp.1345-1347. 10.1007/s11356-012-0789-0 . ineris00961776

HAL Id: ineris-00961776

https://hal-ineris.archives-ouvertes.fr/ineris-00961776

Submitted on 20 Mar 2014

HAL is a multi-disciplinary open access archive for the deposit and dissemination of scientific research documents, whether they are published or not. The documents may come from teaching and research institutions in France or abroad, or from public or private research centers.
L'archive ouverte pluridisciplinaire HAL, est destinée au dépôt et à la diffusion de documents scientifiques de niveau recherche, publiés ou non, émanant des établissements d'enseignement et de recherche français ou étrangers, des laboratoires publics ou privés. 
Perspectives from the French workshop on the development and validation of biomarkers and bioassays for the monitoring of aquatic environments

W. Sanchez, T. Burgeot, O. Perceval

W. Sanchez (corresponding author)

Institut National de l'Environnement Industriel et des Risques (INERIS), unité d'écotoxicologie in vitro et in vivo, 60550 Verneuil en Halatte, France

e-mail: wilfried.sanchez@ineris.fr

T. Burgeot

Institut Français de Recherche pour l'Exploitation de la Mer (IFREMER), unité d'écotoxicologie, 44311 Nantes Cedex 3, France

O. Perceval

Office National de l'Eau et des Milieux Aquatiques (ONEMA), Direction de l'action scientifique et technique, 94300 Vincennes, France 


\section{Workshop objectives and main outcomes}

During the past three decades, there has been an increasing interest in the field of ecotoxicology for development of effect-based monitoring tools (EBMTs) including in vitro tests, biomarkers and whole organism bioassays. This interest is due to the practical application of EBMTs in the surveillance of the quality of water and aquatic ecosystems (ICES, 2008). Within this framework, these ecotoxicological tools seem to offer numerous potential advantages, as they allow one to take into account the cumulative impact of the whole contaminants present in the field, and the bio-available and active fractions of toxicants as well as their degradation bioaccumulation, biotransformation (Lam and Gray, 2003; Hecker and Hollert, 2009). Hence, they are often seen as complementary tools to conventional environmental monitoring approaches, mostly based on the measurement of a predefined list of chemical substances in various aquatic compartments (water, sediments and biota) and the analyses of indices of biological integrity (OSPAR 2004). Due to these research activities, several core EBMTs (SGIMC, 2011) are now well characterised and may be directly used to assess the quality of the aquatic environment under a European consensus (Table 1; Sanchez and Porcher, 2009; Lyons et al., 2010). However, if EBMTs are widely used in research studies and provide, at geographically and temporally limited scales, data on ecotoxicological status of water bodies, few applications of EBMTs are currently implemented in regulatory environmental monitoring programs.

The workshop on "the development and validation of effect-based monitoring tools for aquatic environment monitoring" was held the $17^{\text {th }}$ November 2010 in Verneuil en Halatte, France. It was organized by the French Institute for Industrial Environment and Risks (INERIS), the French Research Institute for Exploration of the Sea (IFREMER) and the French Agency for Water and Aquatic Environments (ONEMA). The major aims of this workshop were i) to compile and review state of art on biomarker and bioassay currently used 
in environmental risk assessment; ii) to identify of scientific and technical limitations hampering the implementation of these biomarkers/bioassays in environmental monitoring programs; and iii) to highlight research needs and organise future applications of EBMTs. Workshop attendees (i.e. representatives of French research institutions, environmental managers and decision makers) agreed on the potential interest of EBMTs for water body and/or effluent monitoring (Table 2). Moreover, the need of EBMT validation and standardisation recognised in national and international quality assurance programmes was clearly identify as a key challenge to be met for these indicators to be deployed in future marine and freshwater environmental monitoring programmes. The French National Reference Laboratory for Water (AQUAREF), the International Council for the Exploration of the Sea (ICES) and the network of reference laboratories for monitoring of emerging environmental pollutants (NORMAN) were considered as suitable European platforms for the validation and standardization of candidate EBMTs. To complete these conclusions, several research needs and knowledge gaps were identified such as the identification of relevant sentinel species, the definition of reference values and assessment criteria and also development of specific tools for data analysis.

\section{Workshop perspectives and current activities}

Since October 2010, several activities were planned and /or organized to facilitate EBMT validation and the methodological transfer to environmental managers in accordance with workshop conclusions. In a first step, an inventory of biomarkers and in vitro bioassays available in French research laboratories was conducted in cooperation with the marine ICES Study Group on Integrated Monitoring of Contaminants and Biological Effects (SGIMC 2011). This work benefited from the contributions by other European countries, including Sweden, Spain, Belgium, Germany, Ireland, Norway, the United Kingdom and The Netherlands. This exhaustive inventory distinguishes well-characterised EBMTs and tools for 
which development is still needed due to a lack of data related to response specificity, basal level or interactions with physiological and environmental factors. This European-wide survey will be integrated in the technical report on effect-based monitoring tools, which is in preparation by the Sub-Group on Chemical monitoring and emerging pollutants (SG-CMEP) of the Working Group E on chemical aspects (WG-E) of the DG Environment of European Commission.

As recommended by workshop attendees, an action aiming at the standardisation of EBMTs was initiated by the French AQUAREF laboratory. During the first year, the aim is to define a clear validation process for biomarkers and bioassays based on the European experience acquired by the ICES Working Group on Biological Effects of the Chemical Contaminants (WGBEC, 2010) and in the NORMAN Working Group on "Validation of biomarkers and bioassays for aquatic environment monitoring" (WG2). In the following years, this methodology will be applied to biological indicators selected in the EBMT inventory by a working group operating under the mandate of AQUAREF. This exercise will entail validation or rejection of EBMTs, or identification of missing data required to define validation status. To complete this work, a comparison study will be organised during Autumn 2012 in collaboration with the NORMAN network (WG2 and WG on "Fieldrelevance based approaches for hazardous pollutant identification” (WG3)). This campaign is designed i) to compare assay performances for a same EBMT; ii) to assess the potential of various EBMTs for a same effect or mechanism of action; and iii) to evaluate various data analysis tools. For this purpose, two river basins exhibiting reference sites and various environmental pressures will be investigated and chemical contamination of investigated sites will be characterized. This comparison study will be opened to all interested institutions and laboratories working on EBMTs and the conclusion will be discussed in relation with the 
ICON marine monitoring programme deployed in the European North-East Atlantic coasts (Hylland et al., 2009).

According to the workshop conclusions, the work on EBMT validation performed by NORMAN and ICON network and AQUAREF laboratory can significantly contribute to the future implementation of these assessment tools in major environmental legislations related to water and aquatic ecosystems and especially in the European Water Framework Directive and the Marine Strategy Framework Directive. Concurrently, this experience seems to be relevant to develop a strong academic research to develop novel biomarkers and bioassays able to address new challenges in ecotoxicology such as emerging pollutants (manufactured nanoparticles, GMOs), or the combined effects of chemical stress and climate change on aquatic ecosystems.

\section{Acknowledgements}

The works presented in the paper were supported by the French Ministry for Ecology and Sustainable Development (MEDDTL, programs 181 and 190) and by the French Agency for Water and Aquatic Environments (ONEMA).

\section{References}

French National Reference Laboratory for Water (AQUAREF). http://www.aquaref.fr/ Hylland K., Lang T., Vethaak D., Thain J., McIntosch A., Burgeot T., Martinez C., 2009. ICON (Integrated assessment of contaminant impacts on the North Sea): An international workshop. $15^{\text {th }}$ Symposium on Pollutant Responses in Marine Organisms, 18-20 May, Bordeaux, France, Poster.

Hecker M., H. Hollert, 2009. Effect-directed analysis (EDA) in aquatic ecotoxicology: State of the art and future challenges. Environmental Science and Pollution Research. 16, 607-613. International Council for the Exploration of the Sea (ICES). http://www.ices.dk/ 
ICES, 2008. Report of the fourth ICES/OPAR Workshop on Integrated Monitoring of Contaminants and their Effects in Coastal and Open sea Areas (WKIMON IV). ICES document CM 2008/ACOM:49 ref.MHC.OSPAR.

Lam P.K.S., J.S. Gray, 2003. The use of biomarkers in environmental monitoring programmes. Marine Pollution Bulletin. 46, 182-186.

Lyons B.P., J.E.Thain, G.D. Stentiford, K. Hylland, I.M. Davies, A.D. Vethaak, 2010. Using biological effects tools to define good environmental status under the european union marine strategy framework directive. Marine Pollution Bulletin. 60, 1647-1651.

Network of reference laboratories for monitoring of emerging environmental pollutants (NORMAN). http://www.norman-network.net/

OSPAR, 2004. OSPAR/ICES Workshop on the evaluation and uptake of background refernce concentrations $(\mathrm{B} / \mathrm{RCs})$ and ecotoxicological assessment criteria contaminants in water, sediment and biota. Hazardous substances series, No, 214.ISBN 1-904426-522, p.169. Sanchez W., J.-M. Porcher, 2009. Fish biomarkers for environmental monitoring within the Water Framework Directive. Trends in Analytical Chemistry. 28. 150-158.

SGIMC, 2011: Report of the Study Group on Integrated Monitoring of Contaminants and biological effects (SGIMC), 14-18 March 2011, Copenhagen, Denmark. ICES CM 2011/ACOM:30 (www.ices.dk). 265 p. 
Table 1. List of core Effect-Based Monitoring Tools (EBMTs) that could be used in environmental monitoring programs (adapted from Sanchez and Porcher, 2009; Lyons et al., 2010).

\begin{tabular}{|c|c|c|}
\hline Type of EBMTs & EBMT name & Data provided \\
\hline In vitro bioassay & DR-CALUX & $\begin{array}{l}\text { Contamination by dioxin-like } \\
\text { compounds }\end{array}$ \\
\hline Biomarker & EROD activity & $\begin{array}{l}\text { Exposure to dioxin-like } \\
\text { compounds }\end{array}$ \\
\hline Biomarker & Vitellogenin & $\begin{array}{l}\text { Exposure to estrogenic } \\
\text { compounds }\end{array}$ \\
\hline Biomarker & Lysosomal stability & General health status \\
\hline Biomarker & Acetylcholinesterase & $\begin{array}{l}\text { Exposure to neurotoxic } \\
\text { compounds }\end{array}$ \\
\hline Whole-organism bioassay & Growth of sea urchin embryo & $\begin{array}{l}\text { Toxic potential of } \\
\text { environmental matrices for } \\
\text { organisms }\end{array}$ \\
\hline Whole-organism bioassay & $\begin{array}{l}\text { Abnormality of bivalve } \\
\text { embryo }\end{array}$ & $\begin{array}{l}\text { Toxic potential of } \\
\text { environmental matrices for } \\
\text { organisms }\end{array}$ \\
\hline
\end{tabular}


Table 2. Summary of workshop conclusions on Effect-Based Monitoring Tools (EBMTs): potential applications according to needs of environmental managers

\begin{tabular}{|l|l|l|}
\hline Needs of environmental & EBMTs and application & Environmental legislation \\
managers & strategies & \\
\hline effluents & In vitro and whole organism & Financial regulation \\
\hline Water body monitoring & Biomarker in wild or caged & WFD, MSFD \\
\hline Monitoring of specific site & Weight of evidence & WFD investigative, MSFD \\
impact & approach, Effect-Directed & monitoring \\
& Analysis & \\
\hline
\end{tabular}

WFD: Water Framework Directive (2000/60/EC); MSFD: Marine Strategy Framework Directive (2008/56/EC) 